\title{
CAMPUS' INFORMAL LEARNING SPACES FOR READING ACTIVITIES AND THEIR RELATION TO UNDERGRADUATES' RESPONSES
}

\author{
Angela Christysonia Tampubolon ${ }^{1 *}$, Hanson E. Kusuma ${ }^{2}$ \\ ${ }^{1}$ Department of Architecture, Petra Christian University, Jalan Siwalankerto 121-131, Surabaya 60236, Indonesia. \\ ${ }^{2}$ Department of Architecture, School of Architecture, Planning, and Policy Development, Institut Teknologi Bandung, Jalan \\ Ganesa 10, Bandung 40132, Indonesia. \\ *Corresponding author; Email: angelact@petra.ac.id; angela.christysonia@gmail.com
}

\begin{abstract}
Potential of informal learning spaces (ILS) in promoting reading activities are one of a theme of space that can be explored in higher education. This explanatory study conducted in Institut Teknologi Bandung (ITB) and was aimed at identifying ILS which preferred by students as reading space and their relation to students' responses. Students tend to choose library ILS but non-library ILS also have potential in supporting the responses to be achieved. Students were found to have better comprehension, a good mood, and to read longer in library ILS. Meanwhile, students found it easier to pay attention and felt an increased desire to engage in discussions in non-library ILS, and tended to visit these more often. At this case study, library ILS tends to be used for individual activities, while non-library ILS are used for collaborative or group activities. Adapting function and type of space between ILS categories can be part of efforts to create learning engagement and to support both individual and collaborative work.
\end{abstract}

Keywords: Campus environment; informal learning space; reading, response; undergraduate students.

\section{INTRODUCTION}

Higher education usually use the term of 'space' and 'environment' as teaching and learning establishment, rather than physical arrangements (Temple, 2008). Recently, interest in exploring the theme of space arise among higher education scholar (Barnacle, 2016). The quality of learning can be developed by using various learning strategies and choosing an appropriate physical environment (Zimmerman and Kitsantas, 2002). Built spaces have physical features that can affect student learning outcomes toward performance, behavior, feeling, and learning ability (Gifford et al., 2011).

The built environment is considered to have a relationship with learning activities undertaken in it e.g (Beckers et al., 2016a). The physical learning space is an integral part of the learning process and has the ability to influence learners (Thomas, 2010) by inducing positive emotional responses. This leads to the enhancement of learning and strengthening the emotional attachment in specific learning spaces (Graetz, 2006).

In the learning environment, there are various educational activities, one of which is reading. Reading is not yet an integral part of social and cultural activities in Indonesia. The reading interest index in Indonesia only reaches 0.001 , i.e. only one out of every 1000 people have an interest in reading (Ditjen PAUD-DIKMAS, 2016). This is considered a concern and needs further investigation. In the present study, reading is defined as a way of learning aimed at self-regulated learning (Zimmerman 2000, 2002) through the selection or seeking of information from different sources, such as textbooks or electronic media (Zimmerman, 2008). Reading activity can be conducted in formal and informal learning context. Identification of spaces that are considered appropriate for and supportive of reading activities can be further conducted.

Research on learning activities tends to focus on primary school classrooms and university lecture rooms but not on informal learning spaces (Scannell et al., 2016), considering student activities likely to be more prevalent found in informal learning spaces (Cross, 2006). Informal learning space (ILS) are a type of space that can be found inside and outside of the campus environment and can be used without having to reserve a place; they can be used both individually and collaboratively (Harrop and Turpin, 2013).

Apart from some studies on the learning environment in higher education, a lack of knowledge about students' experiences in informal social learning spaces exists (Matthews et al., 2011). College students have preferences when it comes to physical learning spaces, so their opinions need to be involved (Fisher and Newton, 2014). In higher education, learning activities not only take place in libraries but also in other areas, such as residences, cafeterias, lounges, empty classrooms, laboratories, and also outdoor settings (Sommer, 1970). Beckers et al. (2016a) 
found that catering areas, cafés, entrances, corridors, project rooms, and personal cockpits within campus are learning spaces that support individual learning activities.

A library is an ILS because it has different functions from a classroom as a formal learning space for prescribed courses or class dictation learning (Montgomery, 2014). Students visit the library to obtain books, journals and materials related to their lessons. Students can also use electronic media to access learning content and materials without having to visit the library (Montgomery, 2014). The possibility of having ILS outside libraries is getting bigger.

Several studies have tried out to discover the relationship among learning environments and cognitive abilities. Cognitive ability tends to be assessed from performance based on the value or achievement of learning on a certain subject (Barrett et al., 2015; Klatte et al., 2017; Plant et al., 2005). Hygge and Knez (2001) found a relationship between heat, lighting and noise on the one hand and the cognitive skills in reading on the other hand. A student's ability to respond to lessons is considered a positive cognitive ability (Benfield et al., 2015). Marchand et al. (2014) have investigated the impact of the classroom on students' comprehensive abilities and perception of the environment. Comprehension, i.e. understanding of reading or listening, is a constructive process that involves interaction between the material read or heard by the learner; the reader or listener can remember the meaning of what is being read or heard (Royer, 2001). Cognitive ability is also seen from reading attention and the ability to concentrate even in high-noise environments (Marchand et al., 2014).

In the literature on classroom environments, the impact of the physical environment on user psychology, such as feeling (mood) and individual perception of environmental impacts on learning, are considered not getting enough concern (Marchand et al., 2014). Feeling is a significant issue that have a contribution on reading comprehension (Bohn-gettler and Rapp, 2011; Egidi and Gerrig, 2009). Noise could predisposes stress, performance, and adaptation; affects the arousal and masking aspects but under some conditions (Szalma and Hancock, 2011).

It can be understood that generally college outcomes can be categorized into the cognitive and affective domain (Astin and Antonio, 2012; Pascarella and Terenzini, 2005). In addition to cognitive and affective responses, this study argues that there are also behavioral responses that are influenced by the physical environment, such as time, intensity and duration of visits, and the reading duration per one time. College students use libraries almost every day or at least once every week (Cunningham and Walton, 2016). This study also argues that open time affects visits, where not all buildings and facilities are open at all times. We found that higher education literature often discuss student outcomes from their achievement in obtaining certain grade or score. In this study, we argues that it is important to understand what academic goals that students constructed to themselves.

Higher education is a highly imagined space that possible to be explored from a range of spatial considerations, including physical (Barnacle, 2016). Looking at the various types of spaces and the reasons for choosing a reading space, there is an argument that certain spatial functions can meet a particular goal to be accomplished. This study was aimed at identifying ILS (in addition to library spaces) within campus that students can use and that support reading activities. This support is related to the response felt by the students when reading in a selected room. The findings emerged the possibilities of higher education in responding issues concern theme of space and reading from different perspective.

\section{METHODOLOGY}

\section{Sample}

Physically, every college has a diversity and difference in the building designs and the availability of facilities. Moreover, each college has various characteristics of their students. Based on this general knowledge, the current study conducted only in one campus environment. Selected Institut Teknologi Bandung (ITB), which is also a part of the top 12 universities in Indonesia (Kemenristek Dikti, 2016, p.29). The study also put the consideration that the entire faculty and respondents were in the same geographical conditions and position. The conditions make the validity of the results of this research is primarily focus on the case study, which is become the limitation for the results.

The respondents were third-grade students (same year of study) from the selected departments with the consideration that they have more understanding and awareness of the campus when compared to first- or second-grade students and are more flexible when compared to final year students (Cunningham and Walton, 2016).

Determination of the respondents was done using non-random purposive sampling (Kumar, 2011). There are 40 departments, from which eight departments were further selected because of their 
locations being scattered and can represent every campus sections. The following departments were selected: West section (with total 194-36.40\%) is represented by Petroleum Engineering (80-15.01\%), Physics (78-14.63\%), and Microbiology (366.75\%); East section (with total 117-21.95\%) is represented by Architecture (87-16.32\%) and Product Design (30-5.63\%); North section is represented by Management (109-20.45\%); Centre/South section (with total 113-21.20\%) is represented by Physics Engineering (74-13.88\%) and Electrical Power Engineering (39-7.32\%).

Data were obtained from 533 respondents, yielding a $14.59 \%$ response rate (there were 3654 third-grade students). To provide at least some adjustment for potential bias, the total of respondents by gender is strived not have a large number of differences (234-43.90\% women; 299-56.10\% men). The current study excluded the social and economic background because the purpose is to know how conscious the students to recognize and use their campus. In addition, all facilities in selected case study can be used for free.

Data collection on the selected types of spaces for reading was done using open-ended questions because each department tends to have different ways of naming spaces and certain departments do not have some types of spaces.

\section{Materials}

In the early stage of research, an open-ended questionnaire about students' responses when reading in a selected room, time, duration, and intensity of visit, and reading duration was distributed between February 20 and March 3, 2017. Qualitative data were acquired from 371 students at 40 departments, which were then analyzed using a qualitative content analysis method.

The content analysis results were used for developing a closed-ended questionnaire for data collection on students' responses when reading in the selected places. The perceived reading responses were 'read faster', 'read more effectively', 'easier understanding', 'knowledge increases', 'better appreciate', 'more serious', 'can imagine', 'read calmly', 'read relaxed', 'comfortable reading', 'more focused', 'feeling happy', 'not easily distracted', 'read longer', 'not easily drowsy', 'not easily bored', 'enjoy reading', and 'the desire for discussion increases'. The questionnaire used a Likert scale from 1 to 5 to indicate whether students agreed or not in sensing a particular response. See Table 1 for the sample questions about reading responses.
From the early stage of research, the results of time, duration, visit intensity, and reading duration per one time were also analyzed using a distribution analysis. From the results of this distribution analysis, each answer was grouped into five categories with equal intervals that were used for developing the answers for the closed-ended questionnaire. Data obtained from the closed-ended question about time of visit are nominal data. Students were asked to choose one from a range of time categories about when they tend to go to ILS for reading: (1) 07:00 a.m. - 10:00 a.m.; (2) 10:01 a.m. - 13:00 p.m.; (3) 13:00 a.m. - 16.00 p.m.; (4) 16:00 p.m. - 19:00 p.m.; or (5) above 19:00 p.m. The data obtained from the questions about visit duration, visit intensity, and reading duration are interval data (see Table 2 for the closed-ended questionnaire on students' behavior).

Data collection was conducted using paperbased questionnaires that were distributed at eight departments from April 3 to April 12, 2017 to each class of third-grade students. For internal consistency reliability, Cronbach's alpha for the whole questionnaire was .87. All standard error of the sample was in range of .03-07.

\section{Data analysis method}

The type of space was obtained by identifying the names mentioned by the students. The data was analysed by using coding which yield a number of frequencies to be analyzed using distribution analysis. We performed analysis of the numeric data from students' reading response and behavior using principal components analysis (PCA) and factor analysis. For PCA, Kaiser's (1960) stopping rule was used to determine the number of principal components (eigenvectors). Kaiser's stopping rule needed to be applied because the number of variables was smaller than 30 or moderate (Bryant and Yarnold, 1995; Pituch and Stevens, 2016). By applying Kaiser's stopping rule, the number of principal components had an eigenvalue greater than 1 . They can be used to represent the measured variables because they have a value that exceeds the variability of the measured variables. The next step was to obtain latent variables (dimensions) that can be easily named by using factor analysis. Varimax orthogonal rotation was used to carry out factor analysis so that the components do not correlate. The factor loading of each measured variable associated with each of the latent variables was calculated to be as large as possible and the factor loading unrelated to the associated latent variables was calculated to be as small as possible. We also performed correspondence 
Table 1. Sample questions about reading responses with Likert scale

\begin{tabular}{|c|c|c|c|c|c|}
\hline \multirow[b]{2}{*}{ Questions } & \multicolumn{5}{|c|}{ A higher number indicates that you agree more with the statement } \\
\hline & $\begin{array}{l}\text { Strongly } \\
\text { disagree }\end{array}$ & Disagree & Do not disagree or agree & Agree & Strongly agree \\
\hline I can read longer & (1) & (2) & (3) & (4) & (5) \\
\hline I can focus more on reading & (1) & (2) & (3) & (4) & (5) \\
\hline I can easier understand & (1) & (2) & (3) & (4) & (5) \\
\hline I can read comfortably & (1) & (2) & (3) & (4) & $(5)$ \\
\hline My desire for discussion increases & (1) & (2) & (3) & (4) & (5) \\
\hline
\end{tabular}

Table 2. Questions about students' behavior with interval scale

\begin{tabular}{lccccc}
\hline \multicolumn{1}{c}{ Questions } & \multicolumn{5}{c}{ Please choose one of the answers to questions below } \\
\hline $\begin{array}{l}\text { How long do you usually stay in that } \\
\text { space? (in minutes). }\end{array}$ & $(1)$ & $(2)$ & $(3)$ & $(4)$ & $(5)$ \\
$\quad$ & $<90$ & $91-120$ & $121-150$ & $151-180$ & $>180$ \\
How many times do you visit the space & $(1)$ & $(2)$ & $(3)$ & $(4)$ & $(5)$ \\
in a week or month? (in times per & $<5$ & $5-8$ & $9-12$ & $13-16$ & $>16$ \\
month). & $(1)$ & $(2)$ & $(3)$ & $(4)$ & $(5)$ \\
How long do you usually read at one & $<30$ & $31-60$ & $61-90$ & $91-120$ & $>120$ \\
time? (in minutes).
\end{tabular}

analysis to get the relation of time of visit towards the type of space. Last, we used analysis of variance (ANOVA) to determine the difference of type of space towards students' reading response and behavior.

\section{RESULTS}

\section{Student preferences for ILS as reading space}

From the open-ended questions about space preferences within campus, several types of spaces used by students for reading were identified. The results were categorized based on ILS function as library or non-library. Each occurrence of an answer to each type of space and category was analyzed using distribution analysis to see whether or not a particular room was selected (see Figure 1 for the distribution analysis results).

For reading some students prefer library spaces, i.e. the university library $(240-45.03 \%)$ or the libraries of their respective departments (98$18.38 \%$ ). There are formal study areas that can be used as non-library ILS, such as classrooms (35 $6.56 \%$ ) and laboratories (29-5.44\%). Laboratories can be divided into studios (12-2.25\%), computer laboratories $(11-2.06 \%)$, and work laboratories (6$1.12 \%)$. This division was made because not all departments have all three types of laboratory for different designations. Several connecting spaces were mentioned, i.e. hallway (20-3.37\%), balcony (18-3.37\%), lobby (4-0.75\%), prayer room (4$0.75 \%)$, and canteen (2-0.37\%), which can be categorized as non-library ILS. Supporting rooms for studying are included in non-library ILS, i.e. empty room (17-3.18\%), exhibition room (3-0.56\%), and seminar room (3-0.56\%). There are also non-library ILS used by students outside academic activities, i.e. student union room (35-6.56\%), student lounge (15$2.81 \%)$, and student clubroom (10-1.87\%).

There are $182-34.15 \%$ men and $156-29.27 \%$ women who selected library ILS, meanwhile 117$21.95 \%$ men and 78-14.63\% women selected nonlibrary ILS. Correspondence between gender and selection of space were found not significant.

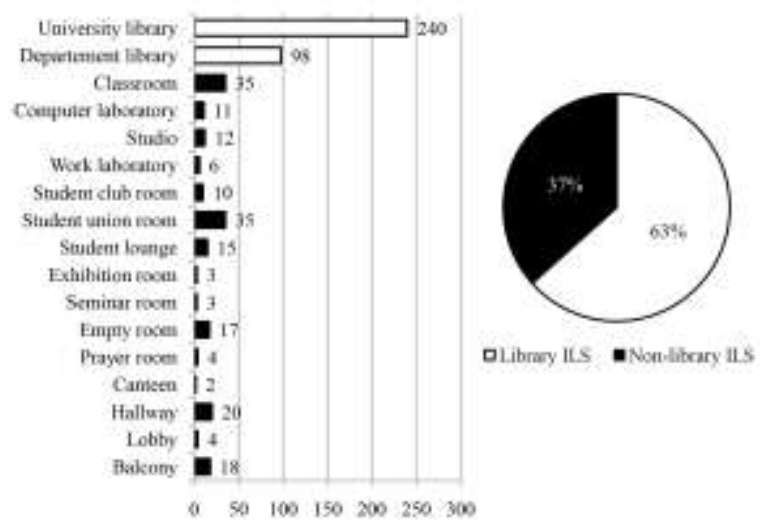

Fig. 1. Distribution analysis of reading space based on informal learning space (ILS) function

\section{Student responses when reading in the selected space}

From the factor analysis results on students' responses, four latent variables (has explained 60.98\% 
Table 3. Factor analysis of student's reading response

\begin{tabular}{lcccccc}
\hline \multicolumn{1}{c}{ Measured variable } & \multirow{2}{*}{$\mathrm{M}$} & $\mathrm{SD}$ & \multicolumn{4}{c}{ Latent variable } \\
\cline { 5 - 7 } & & & Comprehension & Mood & Attention & Discussion \\
\hline Read faster & 3.21 & .88 & $\mathbf{7 4}$ & .03 & .04 & .16 \\
Read more effectively & 3.47 & .81 & $\mathbf{. 7 3}$ & .27 & .03 & .08 \\
Easier understanding & 3.32 & .84 &. $\mathbf{7 2}$ & .17 & .22 & .13 \\
Knowledge increase & 3.44 & .81 & $\mathbf{. 6 7}$ & .16 & .08 & .33 \\
Better appreciate & 3.38 & .88 & $\mathbf{. 6 0}$ & .47 & .20 & -.10 \\
More serious & 3.57 & .85 & $\mathbf{. 5 8}$ & .49 & .13 & -.12 \\
Can imagine & 3.33 & .94 & $\mathbf{. 5 1}$ & .32 & .21 & .13 \\
Read calmly & 3.76 & .83 & .19 & $\mathbf{. 7 9}$ & .00 & -.09 \\
Read relaxed & 3.86 & .75 & .10 & $\mathbf{. 7 5}$ & .01 & .35 \\
Comfortable reading & 3.80 & .77 & .19 & $\mathbf{. 6 7}$ & .19 & .20 \\
More focused & 3.62 & .82 & .49 & $\mathbf{. 5 8}$ & .25 & -.18 \\
Feeling happy & 3.71 & .75 & .15 & $\mathbf{. 5 7}$ & .25 & .48 \\
Not easily distracted & 3.31 & .95 & .34 & $\mathbf{. 5 7}$ & .17 & -.27 \\
Read longer & 3.55 & .80 & .43 & $\mathbf{. 5 2}$ & .13 & .09 \\
Not easily drowsy & 3.06 & .94 & .10 & .03 & $\mathbf{. 9 1}$ & .08 \\
Not easily bored & 3.40 & .83 & .20 & .45 & $\mathbf{. 5 1}$ & .13 \\
Enjoy reading & 3.41 & .81 & .46 & .36 & $\mathbf{. 4 9}$ & -.04 \\
Desire for discussion increases & 3.43 & .98 & .24 & .02 & .06 & $\mathbf{. 7 9}$ \\
\hline
\end{tabular}

Table 4. Factor analysis of students' behavior

\begin{tabular}{lcccc}
\hline \multirow{2}{*}{ Measured variable } & \multirow{2}{*}{ M } & SD & Latent variable \\
\cline { 4 - 5 } & & 1.21 & $\mathbf{. 9 1}$ & Duration of reading \\
\hline Intensity of visit & 2.23 & 1.50 & .77 & .14 \\
Duration of visit & 2.21 & .99 & .03 & .45 \\
Duration of reading & 2.27 & .96 \\
\hline
\end{tabular}

of the total variance) were considered sufficient to describe and represent the phenomena of 18 measured variables. Four latent variables describe and represent three cognitive responses, namely 'comprehension', 'attention', and 'discussion', and one affective response, namely 'mood' (see Table 3 for the factor analysis of students' reading response).

From the factor analysis results on students behavior observed from duration of visit, intensity of visit, and duration of reading, two latent variables (has explained $85.61 \%$ of the total variance) were considered sufficient to describe and represent the phenomena of 3 measured variables. Two latent variables describe and represent behavior, namely 'visiting pattern' and 'duration of reading' (see Table 4 for the factor analysis of student's behavior).

The time of visit to reading spaces can be divided into five categories from 07:00 a.m. to after 19:00 p.m. From distribution analysis, 31 students visited at 07:00 a.m. - 10:00 a.m., 163 students visited at 10:01 a.m. - 13:00 p.m., 204 students visited at 13:01 p.m. - 16:00 p.m., 101 students visited at 16:01 p.m. - 19.00 p.m., and 34 students visited at above 19:00 p.m. The time categories were analyzed according to their relation towards library and non- library ILS on campus with correspondence analysis (see Figure 2 for the correspondence analysis results).

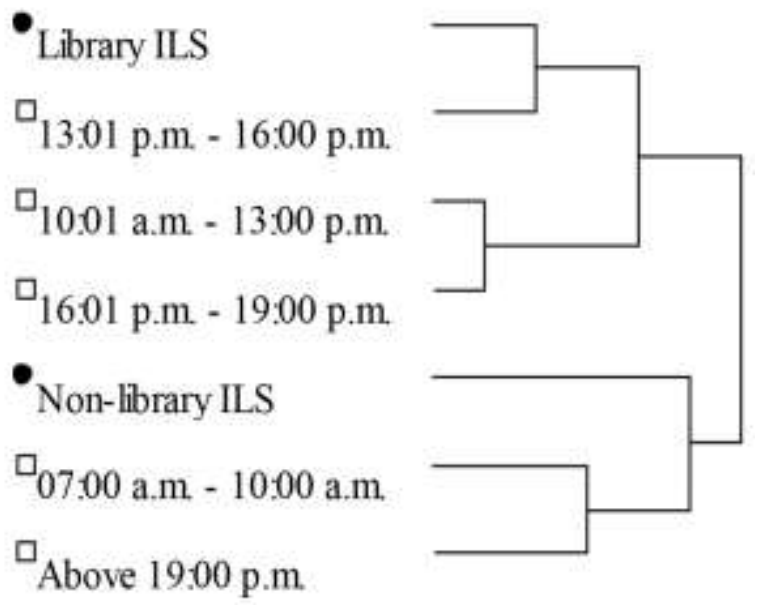

Fig. 2. Correspondence analysis between informal learning space (ILS) categories and time of visit $(\mathrm{P}$-value < .0001)

It showed a tendency toward particular times of visit towards ILS. Students tend to visit non-library ILS between 07:00 a.m. and 10:00 p.m. and after 19:00 p.m. Meanwhile, library ILS tends to be visited around 10:01 a.m. until 19:00 p.m. 


\section{Preference of ILS based in student responses}

After identification of ILS categories and exploration of latent variables in the students' responses, both ILS categories were analyzed using ANOVA to determine if there was any difference with latent variables of cognitive, affective, and behavioral responses. Overall, Table 5 shows the ANOVA of ILS categories with student reading responses. Determination of the significance value was done using Tukey's Honestly Significant Difference (HSD) test 0.05 .

There is a tendency for differences in responses felt by students when they are in a selected ILS. The latent variables 'comprehension', 'mood', and 'duration of reading' tend to be felt more in library ILS. For non-library ILS, students tend to get the latent variables of 'attention', 'discussion', and 'visiting pattern'. The perceived response by gender tends to be no different, except for men who have greater desire for discussion $(\mathrm{p}=0.0003)$ and to get more comprehend $(\mathrm{p}=0.0106)$ than women do.

\section{DISCUSSION}

\section{Library and non-library ILS}

By looking at function (Figure 1), it can be concluded that students tend to prefer library ILS (338 - 63.41\%) over non-library ILS (195-36.59\%). Cunningham and Walton (2016) explain this tendency as being caused by the clarity of the function of the library space and buildings as a support unit of self-regulated learning activities compared with nonlibrary spaces that have functions and activities that tend to vary. Libraries are widely used as places for preparation or revision during exams, doing assignments, meeting friends or colleagues, and completing a final dissertation (Cunningham and Walton, 2016). The emergence of the non-library category reinforces the results of previous researches (Beckers et al., 2016b; Sommer, 1970). Other studies (Beckers et al., 2016a) found catering areas, cafés, entrances, corridors, project rooms, and personal cockpits as supportive spaces. Likewise, in this study other spaces appeared, such as student lounge, student union room, student clubs room, prayer room, and laboratories with various functions. Harrop and Turpin (2013) expressed the purpose of students to visit certain spaces because of a specific environment and resources in the room (e.g., studio or laboratory) as the right place to study. Formal learning spaces, such as a classroom or computer laboratory can be used as long as there are no ongoing activities, and a canteen can be used for group study with a small group (Harrop and Turpin, 2013).

The correspondence analysis result between ILS categories and time of visit (Figure 2) shows that students visit library spaces according to the opening hours. Students tend to visit non-library spaces outside library hours so they will try to find an alternative space whose function can be adjusted to be similar to the function of a library. Therefore, non-library ILS have potential to be used for reading activities. In addition, peak visit hours for ILS are at around noon, especially before and after lunchtime.

\section{Cognitive, affective, and behavioral dimension of student responses}

Based on mean results on Table 1 and 2 of each measured variables, students tend to be between neutral and agree that they have a capability to get the desired cognitive and affective responses (range mean are between 3.06-3.86). For behavior, students consider their visit to the ILS is not frequent (about 5 -8 times per month) but with a long duration (about 91-120 minutes) and can read about 31-60 minutes.

From the results of factor analysis (Table 1 and Table 2), found dimensions of student responses in reading activities that can be viewed cognitively, affectively, and behaviorally. The dimensions can be defined as students' academic goals, which is a cyclical process that helps students to realize that they have a capability to learn, reinforce strategy, become persistence, and proactive (Schunk, 1996; Zimmerman, 2000, 2002).

The latent variable 'comprehension' is a dimension of cognitive response where students feel they can read faster and more effectively, find it easier to

Table 5. Means for ANOVA between informal learning space (ILS) categories and the dimension of students' responses

\begin{tabular}{|c|c|c|c|c|c|c|}
\hline \multirow[t]{2}{*}{$\overline{\mathrm{ILS}}$} & \multicolumn{3}{|c|}{ Cognitive } & \multirow{2}{*}{$\begin{array}{c}\text { Affective } \\
\text { Mood }\end{array}$} & \multicolumn{2}{|c|}{ Behavior } \\
\hline & Comprehension & Attention & Discussion & & $\begin{array}{l}\text { Visiting } \\
\text { pattern }\end{array}$ & $\begin{array}{c}\text { Duration of } \\
\text { reading }\end{array}$ \\
\hline Library & .16 & -.07 & -.17 & .13 & -.43 & .10 \\
\hline Non-library & -.28 & .11 & .29 & -.22 & .74 & -.18 \\
\hline $\mathrm{p}$ & $* * *$ & $*$ & $* * *$ & $* * *$ & $* * *$ & $* *$ \\
\hline
\end{tabular}

Note. ${ }^{*} \mathrm{p}<.05 . * * \mathrm{p}<.01 . * * * \mathrm{p}<.001$ 
understand the reading material, and their knowledge increases. By more appreciative, serious, and imaginative reading, students gain a better understanding of the contents of the reading. Student comprehension constitute the positive cognitive ability (Benfield et al., 2015).

Other cognitive responses are explained by the latent variable 'attention' with the ability to not be easily drowsy as a dominant factor. Students feel that the focus of attention increases when they do not feel bored easily and can enjoy reading. This relates to a student's ability to concentrate in the chosen space and pay attention during reading (Marchand et al., 2014).

Apart from individual studying, the students feel an increased desire to interact with others by conducting discussions. In this research, the latent variable 'discussion' is classified as a form of cognitive response because it is a desire and not yet implemented. In contrast to previous research that looked at the impact of learning based on value or achievement (Barrett et al., 2015; Klatte et al., 2017; Plant et al., 2005), a cognitive response in reading was found when looking at the ability of students to comprehend the reading, the ability to give full attention, and the willingness to discuss.

In addition to the reading response, the latent variable 'mood' was found, which is a part of affective response. Students feel calm, relaxed, and comfortable when reading. The mood for reading becomes better and more time is spent reading when students are not distracted. The measured variables are found to be in the positive term. This could be caused by the expectation of the reader to feel the cognitive impact of comprehension of the text (Bohngettler and Rapp, 2011; Egidi and Gerrig, 2009).

On the PANAS scale (Positive and Negative Affect Schedule; Watson et al., 1988) there are 10 items on the mood scale that independently explain two dominant polar positions, i.e. positive and negative feelings. This research found that students choose to focus on positive feelings when a response needs to be achieved. There is similarity between the measured variable 'feeling happy' toward the PANAS item 'excited', and between the measured variables 'more focus', 'not easily distracted' and 'read longer' toward the PANAS item 'attentive'. Feeling calm, relaxed, and comfortable can be characterized as highly positive affects. These three variables have a similarity to the PANAS-X item 'serenity' (PANAS Extended Form; Watson and Clark, 1999).

The latent variable 'visiting pattern' explains how often students visit and how long they stay in the selected space. Duration of visit is not equal to students' reading duration. Visiting patterns explain students' willingness to visit and use learning facilities (Cunningham and Walton, 2016). There is also the latent variable 'reading duration', a factor that directly describes how long a student usually reads. Plant et al. (2005) explain that students who spend more time studying may get a positive effect with cumulative GPA results. However, this reading duration has nothing to do with SAT because this test determines learning ability, not how much time students spend studying.

\section{Relation between ILS categories and dimension of students responses}

From the results of ANOVA (Table 3) were found the differences between ILS categories toward students' cognitive, affective, and behavioral responses. Students find that they have easier understanding, their knowledge increases, and their reading activities feel faster and more effective in library ILS ( $\mathrm{p}<.0001)$. In non-library ILS, students tend to find themselves not easily drowsy or tired, enjoy their reading $(p=0.0444)$, and have a desire to discuss certain topics ( $\mathrm{p}$.0001). According to the ANOVA results of three latent cognitive response variables and ILS categories, current library ILS are considered to be less suitable if used for interaction with others. Library ILS tend to support individual learning activities.

Students find themselves able to maintain their mood while reading in the library ILS $(\mathrm{p}=0.0001)$. The ability to increase the cognitive response 'comprehension' and the affective response 'mood' is apparently related to the behavioral response 'reading duration'. The duration of reading in the library ILS tends to be longer than in non-library ILS ( $\mathrm{p}=$ 0.0014). This finding is similar to Bohn-gettler and Rapp (2011), who found that mood plays an important role in the success of text comprehension and that there is a relationship between mood and reading resilience (PANAS item 'attentive'; Watson et al., 1988).

Students tend to visit non-library ILS more than library ILS ( $\mathrm{p}<.0001)$. This can be influenced by the cognitive responses 'reading attention' and 'discussion', which are more perceived when in non-library ILS. It should be considered that non-library ILS can accommodate more different activities. Students can eat, talk, do homework, relax, discuss, assemble, and do other activities. The opportunity to perform more activities makes the intensity and duration of visits to non-library ILS higher. By this explanation, non- 
library ILS tend to accommodate collaborative or group learning activities.

From the ANOVA result of the ILS categories and student responses, there are two types of spaces that can be used to read, namely individual and collaborative/group learning spaces. The reading space types can be interpreted based on engagement, which is an attempt to increase satisfaction, divert boredom, increase motivation and involvement of students in relation to school activities, improve student attainment, and to understand the positive development of each student (Fredricks et al., 2004). Student engagement has a prominent position in higher education that can explain both institution and student quality and development (Axelson and Flick, 2010; Zilvinskis et al., 2017).

Fredricks et al.'s (2004) described engagement as a model of multidimensional construct consisting of three dimensions, namely behavioral, cognitive, and emotional. In individual learning spaces, which can be found in library ILS, the dimension of cognitive and emotional engagement tends to be formed. Cognitive engagement refers to the reader's willingness and awareness in understanding, mastering difficult tasks, and trying to use learning strategies. Meanwhile, emotional engagement refers to positive and negative feelings, including indicators of interest and happiness, as well as lack of boredom, anxiety, and sadness (Fredricks et al., 2004). In collaborative or group learning spaces, which can be found in non-library ILS, the dimension of behavioral engagement tends to be formed. This dimension can be observed by interaction between persons, visiting patterns, or their efforts to participate in academic activities, such as asking or giving attention (Fredricks et al., 2004).

\section{Implications}

Seeing the role of engagement in student development, a recommendation that can be done is to adjust the functions and types of spaces in campus environments to support both individual and collaborative/group reading activities. An example of space adjustment in ITB campus can be seen in Figure 3.

This study found that not all responses tend to be fully experienced by students in one type of space. Support for the concept of engagement in ILS is expected to have a positive impact on improving the quality and motivation of learning. These findings can be incorporated into the planning and design of ILS as part of student learning support units by adjusting library and non-library functions so that in a facility or building there are various spaces for reading to choose from. Students also have more opportunities to visit and spend time due to the presence of non-library spaces that tend to be open longer.

\section{CONCLUSION}

The study responds the theme of space in higher education, especially in term of informal learning space. The study identified the type of informal

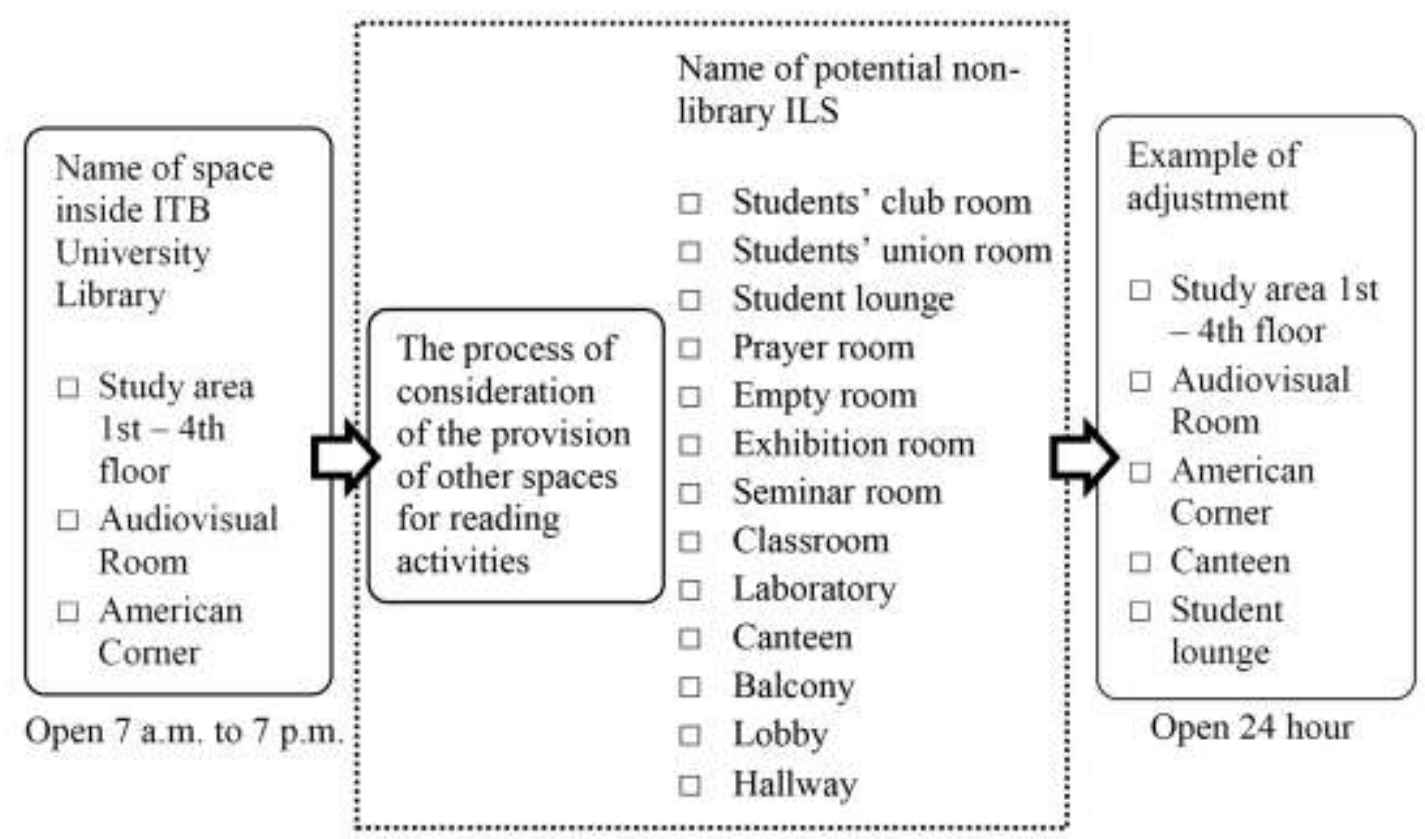

Fig. 3. Example of the adjustment of informal learning space (ILS) function and type of space 
learning space that supports students' reading activities and goals, yielding three major findings. First, various possible learning activities (including reading) can be conducted in informal learning space, both library and non-library. Second, students generally constructed their reading goals based on the cognitive and affective domain. Students also have the behavioral response from the viewpoint of visiting pattern and reading duration. Students responded from a positive point of view, i.e. they already have the objective of getting a positive feeling from reading in the selected space. Third, students perceived responses differently towards the type of informal learning space. Based on the responses, it can be concluded that the library ILS are appropriate as individual learning spaces, while non-library ILS are appropriate as collaborative or group learning spaces. This response can be interpreted as a form of engagement and the consideration of adjusting many forms of space emerged. Engagement has a role in improving the quality and achievement of learning. By adjustment of a space, students potentially can perform reading activities either individually or collaboratively.

The findings show that every corner of space in higher education environment has a possibility in support students to become self-regulate for achieving their goals. Every place has characteristics that make users perceived the possibility of its function. By finding out that every space could fulfill particular responses, emerged the possibilities of higher education in responding issues related to teaching and learning establishment from perspective of physical arrangements.

This study focused on one university and made the results has its limit. Every university has different characteristics and is expected to yield different results. Views from all types of users need to be included so that every ILS provided on campus can function well as a reading space and provide direct benefit. Using larger samplings (e.g., selecting more than one university) could give more reliable and generalize results. The prospective user's views can also be a potential subject in studying characteristics expected from ILS. Investigation of the responses can provide additional knowledge in planning and design for campus environments.

\section{REFERENCES}

Astin, A.W., \& Antonio, A. L. (2012). Assessment for excellence: The philosophy and practice of assessment and evaluation in higher education (2nd ed.). Lanham, Maryland: Rowman \& Littlefield.
Axelson, R. D., \& Flick, A. (2010). Defining student engagement. Change: The Magazine of Higher Learning, 43(1), 38-43. https://doi.org/10.1080/ 00091383.2011 .533096

Barnacle, R. (2016). New frontiers: Exploring the space/s of higher education. Higher Education Research and Development, 35(1), 1-3. https://doi.org/10.1080/07294360.2016.1142362

Barrett, P., Davies, F., Zhang, Y., \& Barrett, L. (2015). The impact of classroom design on pupils' learning: Final results of a holistic, multilevel analysis. Building and Environment, 89, 118-133. https://doi.org/10.1016/j.buildenv. 2015. 02.013

Beckers, R., Voordt, T. Van Der, \& Dewulf, G. (2016a). Learning space preferences of higher education students. Building and Environment, 104, 243-252. https://doi.org/10.1016/j.buildenv.2016.05.013

Beckers, R., Voordt, T. Van Der, \& Dewulf, G. (2016b). Why do they study there? Diary research into students' learning space choices in higher education. Higher Education Research \& Development, 35(1), 142-157. https://doi.org/ 10.1080/07294360.2015.1123230

Benfield, J. A., Rainbolt, G. N., Bell, P. A., \& Donovan, G. H. (2015). Classrooms with nature views: Evidence of differing student perceptions and behaviors. Environment and Behavior, 47(2), 140-157. https://doi.org/10.1177/001391 6513499583

Bohn-gettler, C. M., \& Rapp, D. N. (2011). Depending on my mood: Mood-driven influences on text comprehension. Journal of Educational Psychology, 103(3), 562-577. https://doi.org/10. 1037/a0023458

Bryant, F. B., \& Yarnold, P. R. (1995). Principalcomponent analysis and exploratory and confirmatory factor analysis. In Reading and Understanding Multivariate Statistics (p. 99130). Washington, DC: American Psychological Association.

Cross, J. (2007). Informal learning: Rediscovering the natural pathways that inspire innovation and performance. San Francisco, CA: Pfeiffer.

Cunningham, M., \& Walton, G. (2016). Informal learning spaces (ILS) in university libraries and their campuses: A Loughborough University case study. New Library World, 117(1/2), 4962. https://doi.org/10.1108/NLW-04-2015-0031

Ditjen PAUD-DIKMAS. (2016, April 12). Gerakan Indonesia Membaca: "Menumbuhkan Budaya Membaca." Kementerian Pendidikan Dan Kebudayaan: Direktorat Jenderal Pendidikan Masyarakat. Retrieved from https://www.pauddikmas.kemdikbud.go.id/berita/8459.html 
Egidi, G., \& Gerrig, R. J. (2009). How valence affects language processing: Negativity bias and mood congruence in narrative comprehension. $\mathrm{Me}$ mory \& Cognition, 37(5), 547-555. https://doi. org/10.3758/MC.37.5.547

Fisher, K., \& Newton, C. (2014). Transforming the twenty-first-century campus to enhance the netgeneration student learning experience: using evidence-based design to determine what works and why in virtual/physical teaching spaces. Higher Education Research \& Development, 33(5), 903-920. https://doi.org/10.1080/072943 60.2014.890566

Fredricks, J. A., Blumenfeld, P. C., \& Paris, A. H. (2004). School engagement: Potential of the concept, state of the evidence. Review of Educational Research, 74(1), 59-109. https://doi.org/ 10.3102/00346543074001059

Gifford, R., Steg, L., \& Reser, J. P. (2011). Environmental psychology. In P. R. Martin, F. M. Cheung, M. Knowle, M. Kyrios, L. Littlefield, J. B. Overmier, \& J. M. Prieto (Eds.), IAAP handbooks of applied psychology (440-470). London: Blackwell Publishing Ltd. https://doi.org/ 10.1002/9781444395150.ch18

Graetz, K. A. (2006). The psychology of Learning Environments. In D. Oblinger \& J. K. Lippincott (Eds.), Learning Spaces (60-75). Brockport Bookshelf. Retrieved from https://www.educause.edu/ir/library/pdf/P7102cs20.pdf

Harrop, D., \& Turpin, B. (2013). A study exploring learners' informal learning space behaviors, attitudes, and preferences. New Review of Academic Librarianship, 19(1), 58-77. https://doi.org/10.1080/13614533.2013.740961

Hygge, S., \& Knez, I. (2001). Effects of noise, heat and indoor lighting on cognitive performance and self-reported affect. Journal of Environmental Psychology, 21(3), 291-299. https://doi. org/10.1006/jevp.2001.0222

Kaiser, H. F. (1960). The application of electronic computers to factor analysis. Educational and Psychological Measurement, 20(1), 141-151. https://doi.org/10.1177/001316446002000116

Kemenristek Dikti. (2016). Laporan Tahunan Kementerian Riset, Teknologi, dan Pendidikan Tinggi Republik Indonesia 2016. Retrieved from https://ristekdikti.go.id/epustaka/laporan-tahunan-2016/\#book/

Klatte, M., Spilski, J., Mayerl, J., Möhler, U., Lachmann, T., \& Bergström, K. (2017). Effects of aircraft noise on reading and quality of life in primary school children in Germany: Results from the NORAH Study. Environment and
Behavior, 49(4), 390-424. https://doi.org/10. $1177 / 0013916516642580$

Kumar, R. (2011). Research Methodology: a step by step guide for beginners. Los Angeles: SAGE Publications.

Marchand, G. C., Nardi, N. M., Reynolds, D., \& Pamoukov, S. (2014). The impact of the classroom built environment on student perceptions and learning. Journal of Environmental Psychology, 40, 187-197. https://doi.org/10.1016/ j.jenvp.2014.06.009

Matthews, K. E., Andrews, V., \& Adams, P. (2011). Social learning spaces and student engagement. Higher Education Research \& Development, 30(2), 105-120. https://doi.org/10.1080/07294 360.2010 .512629

Montgomery, S. E. (2014). Library space assessment: User learning behaviors in the library. Journal of Academic Librarianship, 40(1), 70-75. https://doi. org/10.1016/j.acalib.2013.11.003

Pascarella, E. T., \& Terenzini, P. T. (2005). How college affects students: A third decade of research. (Vol. 2). San Francisco, CA: JosseyBass.

Pituch, K. A., \& Stevens, J. P. (2016). Applied multivariate statistics for the social sciences: Analyses with SAS and IBM's SPSS (6th ed.). New York, NY: Routledge.

Plant, E. A., Ericsson, K. A., Hill, L., \& Asberg, K. (2005). Why study time does not predict grade point average across college students: Implications of deliberate practice for academic performance. Contemporary Educational Psychology, 30(1), 96-116. https://doi.org/10.1016/ j.cedpsych.2004.06.001

Royer, J. M. (2001). Developing reading based listening tests comprehension Sentence Sentence Verification Technique (SVT). Journal of Adolescent \& Adult Literacy, 45(1), 30-41. Retrieved from https://search.proquest.com/ docview/216912160?accountid $=31562$

Scannell, L., Hodgson, M., Villarreal, J. G. M., \& Gifford, R. (2016). The role of acoustics in the perceived suitability of, and well-being in, informal learning spaces. Environment and Behavior, 48(6), 769-795. https://doi.org/ $10.1177 / 0013916514567127$

Schunk, D. H. (1996). Goal and self-evaluative influences during children's cognitive skill learning. American Educational Research Journal, 33(2), 359-382. https://doi.org/10. 3102/00028312033002359

Sommer, R. (1970). The ecology of study areas. Environment and Behavior, 2(3), 271-280. https://doi.org/10.1177/001391657000200302 
Szalma, J. L., \& Hancock, P. A. (2011). Noise effects on human performance: A meta-analytic synthesis. Psychological Bulletin, 137(4), 682707. https://doi.org/10.1037/a0023987

Temple, P. (2008). Learning spaces in higher education: An under-researched topic. London Review of Education, 6(3), 229-241. https://doi. org/10.1080/14748460802489363

Thomas, H. (2010). Learning spaces, learning environments and the dis "placement" of learning. British Journal of Educational Technology, 41(3), 502-511. https://doi.org/10.1111/j.14678535.2009.00974.x

Watson, D., \& Clark, L. A. (1999). The PANAS-X: Manual for the positive and negative affect schedule-expanded form. Iowa Research Online, 277(6), 1-27. https://doi.org/10.1111/ j.17424658.2010.07754.x

Watson, D., Clark, L. A., \& Tellegen, A. (1988). Development and validation of brief measures of positive and negative affect: The PANAS scales. Journal of Personality and Social Psychology, 54(6), 1063-1070. https://doi.org/10.1037/00223514.54.6.1063
Zilvinskis, J., Masseria, A. A., \& Pike, G. R. (2017). Student engagement and student learning: Examining the convergent and discriminant validity of the revised National Survey of Student Engagement. Research in Higher Education, 58(8), 880-903. https://doi.org/10. 1007/s11162-017-9450-6

Zimmerman, B. J. (2000). Self-efficacy: An essential motive to learn. Contemporary Educational Psychology, 25(1), 82-91. https://doi.org/10. 1006/ceps.1999.1016

Zimmerman, B. J. (2002). Becoming a self-regulated learner: An overview. Theory Into Practice, 41(2), 64-70. https://doi.org/10.1207/s15430421 tip4102_2

Zimmerman, B. J. (2008). Investigating self-regulation and motivation: Historical background, methodological developments, and future prospects. American Educational Research Journal, 45(1), 166-183. https://doi.org/10.3102/0002831 207312909

Zimmerman, B. J., \& Kitsantas, A. (2002). Acquiring writing revision and self-regulatory skill through observation and emulation. Journal of Educational Psychology, 94(4), 660-668. https://doi. org/10.1037//0022-0663.94.4.660 